\title{
Konflik Kepentingan Antara Pimpinan Daerah dan DPRD Dalam Penyusunan Anggaran Pendapatan Belanja Daerah
}

\author{
Anastacia Patricia Novlina Nurak ${ }^{1 *}$, Sri Budi Eko Wardani ${ }^{2}$ \\ ${ }^{1}$ Universitas Indonesia, Depok, Indonesia, email: patricianovlina@gmail.com \\ 2Universitas Indonesia, Depok, Indonesia, email: sbe_wardani@yahoo.com \\ *Koresponden Penulis
}

\section{Info Artikel}

Submit: 09 Des 2020

Accepted: 17 Jan 2021

Publish: 25 Jan 2021

Keywords:

Conflict of Interest, Local

Leader, Local Legislative

Assembly, Local Government

Budget

Kata Kunci:

Konflik Kepentingan, DPRD,

Bupati, APBD

\section{(cc) EY-SA}

Lisensi: cc-by-sa

\begin{abstract}
This research aims to explain about conflict between Sikka's Local Leader and the Local Legislative Assembly (DPRD) in preparation of Local Government Budget (APBD) for term 2019 year. Sikka regencies is one of district that led by candidate from independent line. Fransiskus Roberto Diogo, (Roby Idong) and Romanus Woga won the District Election Head at 2018 without any party nor coalition. Problem arise when Local Leaders and members of Local Legislative Assembly did not reach mutual agreement about house and communication allowance budget. This research uses qualitative methods with primary data sourced from indepth interviews with all parties in the conflict. This research used Maswadi Rauf's conflict theory, which is classified based on the results of research by Mark and Synder. In addition, it is known that there are conflicting interests between Local Leader and Local Legislative Assembly about budgeting. Meanwhile, Local Leader in Sikka aim to control Local Legislative Assembly with negative issue about marking up budget of house and transportation allowances, but thus assembly obtain to increase the budgeting for their right.
\end{abstract}
Abstrak
Penelitian ini bertujuan untuk melihat konflik antara Bupati dan DPRD Kabupaten Sikka dalam penyusunan APBD tahun anggaran 2019. Kabupaten Sikka merupakan salah satu kabupaten yang dipimpin oleh pasangan dari jalur perseorangan untuk pertama kalinya. Permasalahan muncul ketika pembahasan terkait tunjangan perumahan dan tunjangan transportasi anggota legislatif dalam APBD (Anggaran Pendapatan Belanja Daerah) tahun anggaran 2019. Hal ini menimbulkan konflik dengan anggota legislatif dan Banggar yang menyusun angka tunjangan yang lebih tinggi dari yang ditetapkan oleh Bupati Roby Idong. Penelitian ini menggunakan metode penelitian kualitatif dengan data primer bersumber dari in-depth interview bersama pihak-pihak yang mengalami konflik. Selain itu, diperkaya dengan data sekunder yang diambil dari berbagai media lokal. Penelitian ini menggunakan teori konflik dari Maswadi Rauf yang penggolongan nya berdasarkan hasil penelitian dari Mark dan Synder. Selain itu, diketahui bahwa terdapat kepentingan dari Bupati maupun DPRD yang berkonflik. Kepentingan tersebut terkait dengan pelemahan karakter dari DPRD yang sedang dalam masa kampanye menuju pemilihan anggota legislatif (pileg) tahun 2019. Hal ini berkaitan erat dengan kemenangan Bupati terpilih dari jalur perseorangan, sehingga sangat minim dukungan dari anggota legislatif yang berasal dari partai yang menolak mendukung Bupati sewaktu 
mencalonkan diri pada pemilihan kepala daerah (Pilkada) tahun 2018. Sementara kepentingan dari DPRD ialah mendapatkan kenaikan tunjangan perumahan dan transportasi.

\section{PENDAHULUAN}

Dinamika politik lokal di Indonesia terus mengalami perubahan. Salah satu titik balik perubahan politik nasional dan lokal di Indonesia ditandai dengan reformasi tahun 1998 (Sudirman, 2012; Masyrofah, 2013; Hutapea, 2015; Ananta, 2016; Ramdhani, 2019). Reformasi politik ini menghasilkan amandemen UUD 1945 sebanyak 4 kali yakni pada tahun 1999, 2000, 2001 dan 2002. Dalam perubahan amandemen tersebut, terdapat perubahan yang mengatur wewenang kelembagaan eksekutif dan legislatif dan pemerintahan daerah. Salah satunya seperti pengesahan UU Nomor 4 Tahun 1999 yang mengatur tentang susunan dan kedudukan MPR-DPR-DPRD (Eddyono, 2010; Widodo, 2014; Supena, 2018). Tidak hanya mengatur wewenang kelembagaan tetapi juga mengatur mengenai keuangan daerah, yang mana tiap daerah bebas mengatur anggaran belanja dan mengelola pendapatannya masing-masing.

Keuangan daerah di tingkat provinsi ataupun kabupaten/kota dikenal dengan istilah APBD atau Anggaran Pendapatan dan Belanja Daerah. APBD merupakan rencana keuangan pemerintah daerah selama satu tahun yang ditetapkan lewat peraturan daerah. APBD disusun sesuai dengan kebutuhan penyelenggaraan pemerintah daerah dan pendapatan daerah (Pramono, 2014; Barbakem et al., 2018). Penyusunan APBD ini selalu berpedoman pada rencana kerja pemerintah daerah yang telah dikoordinasikan bersama pada waktu sebelumnya. Menurut UU No 17 tahun 2003 APBD terdiri atas Anggaran Pendapatan, Anggaran Belanja dan Pembiayaan. Pada umumnya di berbagai pengertian disebutkan juga APBD meliputi belanja daerah, pendapatan daerah, dan pembiayaan daerah (Halim \& Abdullah, 2006; Oktora \& Pontoh, 2013).

Adapun sumber pendapatan daerah berasal Pendapatan Asli Daerah (PAD), pos Dana Perimbangan dan pos lain-lain Pendapatan Daerah yang sah (Ferdian, 2013). Dalam pos PAD ini terdapat Pajak Daerah dan Retribusi Daerah yang berasal dari wajib pajaknya. Selanjutnya untuk Dana Perimbangan merupakan dana yang diperoleh pemerintah daerah dari pemerintah pusat sebagai wujud pelaksanaan desentralisasi fiskal. Selain sumber pendapatan yang diperoleh dari daerah tersebut dan pemerintah pusat, pemerintah daerah juga memperoleh pendapatan daerah lain yang berupa komponen Dana Bagi Hasil Pajak dari provinsi dan pemerintah daerah lainnya yang ada di dalam pos lain-lain Pendapatan Daerah yang Sah Williantara \& Budiasih, 2016; Widiasih \& Gayatri, 2017; Yasin, 2020).

Terdapat empat pos utama di dalam belanja daerah yaitu pos Belanja Pegawai, pos Belanja Barang dan Jasa, pos Belanja Modal, dan pos Belanja lainnya (Oktora \& Pontoh, 2013; Lontaan \& Pangerapan, 2016; Rahmawati \& Fajar, 2017). Komponen belanja daerah merupakan perwujudan pemerintah daerah dalam mengeluarkan uangnya untuk pelayanan publik. Seringkali dalam pelaksanaannya, terjadi defisit APBD yakni jumlah anggaran belanja lebih banyak dari pendapatan (Asari \& Suardana, 2018). Belum terciptanya kemandirian APBD seringkali membuat tiap daerah lebih besar anggaran belanja dan pembiayaan dibanding pendapatan. Secara agregat nasional defisit APBD di tiap kabupaten selalu meningkat. Menurut laporan ringkasan APBN-APBD tahun 2018 yang dirilis DJPK (Direktorat Jenderal Perimbangan Keuangan) terjadi peningkatan anggaran belanja di tiap kabupaten secara nasional dari tahun 2017 ke 2018 sebesar 4,5\% dan peningkatan defisit sebanyak 7,7 \%. Berikut adalah proses perencanaan dan penganggaran APBD berdasarkan pedoman penyusunan dari Kementerian Dalam Negeri. 


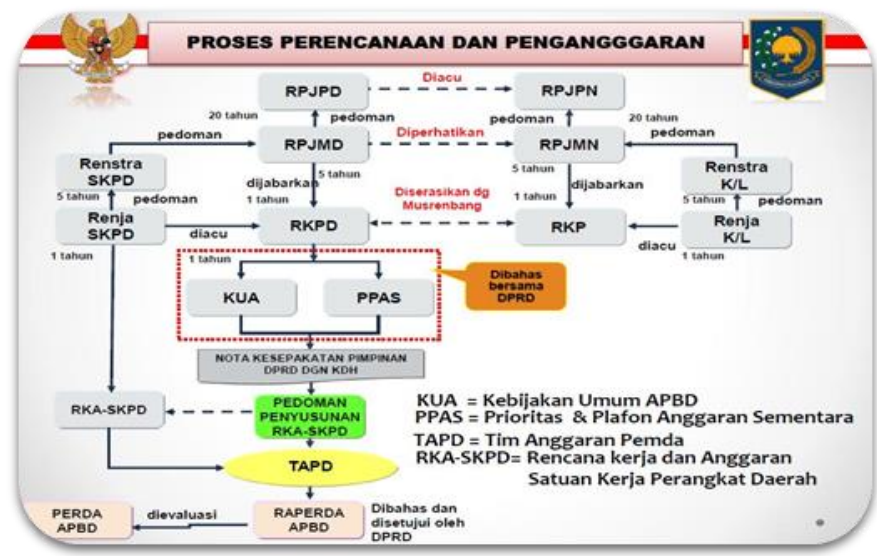

Gambar 1. Proses Perencanaan dan Penganggaran APBD

Sumber: Paparan Dirjen Bina Keuangan Daerah dalam Rapat Kerja Keuangan Daerah Tahun 2018 dan Sosialisasi Permendagri No. 38 Tahun 2018 Tentang Pedoman Penyusunan APBD Tahun 2019

Perencanaan dan penganggaran APBD melalui proses yang panjang dan mengacu serta berpedoman pada RPJPN atau Rencana Pembangunan Jangka Panjang Nasional (Ibrahim, 2014; Tim Kajian PKP2A III LAN Samarinda, 2010). RPJPN ini merupakan pedoman nasional yang disusun untuk 20 tahun dan yang saat ini sedang berlaku adalah RPJN 2005 - 2025. RPJPN menjadi pedoman dasar yang menjadi acuan bagi pemerintah, masyarakat serta dunia usaha dalam mewujudkan cita-cita dan tujuan Nasional. RPJPN menjadi pedoman rujukan dalam merencanakan dan menganggarkan APBD (Sofianto, 2019).

Dikarenakan APBD ini merupakan salah satu bentuk resources bagi pemerintah, maka tak jarang terjadi perbedaan pendapat dalam penyusunan RAPBD maupun ketika akan melakukan pengesahan APBD. Perbedaan pendapat ataupun pemahaman ini, biasanya terjadi antara lembaga eksekutif dan legislatif sehingga berujung pada konflik yang menyebabkan realisasi APBD menjadi terhambat. Salah satunya seperti konflik politik antara kepala daerah dengan DPRD, yakni antara Gubernur DKI Jakarta dan DPRD dalam proses penetapan APBD tahun 2015. Dalam kasus di DKI Jakarta, konflik politik antara Gubernur dan DPRD memiliki perbedaan kepentingan terutama dalam pengelolaan sumber daya (resources). Perbedaan kepentingan ini membuat pemerintahan daerah terbelah (divided government) sehingga menyebabkan lambatnya pengesahan APBD DKI Jakarta yang berdampak secara luas hingga pemberian sanksi oleh Kementerian Dalam Negeri (Puspitasari, 2013). Semangat awal otonomi daerah untuk mendekatkan pemerintah pada masyarakat melalui pelayanan publik tidak dapat berjalan. Sebagaimana diketahui, diharapkan otonomi daerah pada tingkat kabupaten menjadi tingkat satuan terdekat yang bersentuhan langsung dengan masyarakat sehingga mampu mengetahui, dan memenuhi kepentingan masyarakatnya (Ramdhani \& Subekti, 2020).

Salah satu bentuk konflik kepentingan yang akan dibahas yakni antara Kepala Daerah/Bupati dengan DPRD (Dewan Perwakilan Rakyat Daerah) Kabupaten Sikka, Provinsi Nusa Tenggara Timur (NTT). Konflik tersebut berasal dari penolakan terhadap penetapan Peraturan Bupati atau Perbup Nomor 33 Tahun 2018. Awalnya, perencanaan APBD Kabupaten Sikka untuk tahun 2019 telah dipersiapkan oleh pemerintah daerah dan tim badan anggaran DPRD dimana mengatur nominal tunjangan Perumahan dan Transportasi anggota legislatif sesuai Perbup 45/2017. Namun RAPBD 2019 ini ditolak oleh Bupati Sikka yang baru dilantik pada September 2018 yakni Bupati Sikka Fransiskus Robertus Diogo atau akrab disapa Roby Idong. Berikut rincian Perbup yang menjadi akar permasalahan. 
Tabel 1. Rincian Peraturan Bupati Yang Diperebutkan Pada APBD 2019

\begin{tabular}{lcc}
\hline \multicolumn{1}{c}{ Keterangan } & Perbup 45/2017* & Perbup 33/2018** \\
\hline Tunjangan Perumahan per bulan/anggota legislatif & Rp 10.000.000 & Rp 6.250.000 \\
Tunjangan Transportasi per bulan/anggota & Rp 12.500.000 & Rp 9.000.000 \\
\hline
\end{tabular}

*Perbup 45/2017 : Perbup yang dikeluarkan Bupati 2013-2018 (Bupati Yosep Ansar Rera) dan telah di realisasikan selama tahun 2018

**Perbup 33/2018 : Perbup yang dikeluarkan Bupati 2018-2023 (Bupati Robi Idong) dan ditolak DPRD untuk direalisasikan pada APBD 2019

Sumber: JDIH Kabupaten Sikka

Berdasarkan tabel diatas, dapat kita lihat nominal tunjangan transportasi dan perumahan anggota DPRD mengalami penurunan jika dibandingkan dengan anggaran pada APBD 2018. Keputusan Bupati Sikka Fransiskus Robertus Diogo atau akrab disapa Roby Idong untuk memotong anggaran tunjangan perumahan dan transportasi anggota DPRD lewat Perbup 33/2018 seperti pada tabel diatas memicu konflik kepentingan antara lembaga eksekutif dan legislatif ini. Pemotongan dana tunjangan ini merupakan sebuah kerugian bagi pihak DPRD karena tunjangan merupakan salah satu sumber daya ekonominya, sehingga akhirnya menyebabkan konflik dengan Bupati. Hal ini dapat kita lihat menggunakan preposisi penyebab konflik menurut Rauf (2000) yang mengatakan konflik politik ditimbulkan oleh adanya keterbatasan sumber daya dan posisi (resources and positions scarcity). Semakin besar tingkat kelangkaan sumber-sumber daya yang dibutuhkan untuk hidup, semakin besar kemungkinan terjadinya konflik politik. Menggunakan preposisi teori ini, maka tunjangan dalam APBD 2019 ini merupakan wujud resources scarcity dan jabatan sebagai Bupati serta DPRD merupakan wujud dari positions scarcity.

Sehingga, ketika terjadi perbedaan pandangan antara pemerintah dan DPRD dalam Perbup-perbup tersebut, muncul berbagai spekulasi bahwa DPRD melakukan mark up tunjangan karena telah menikmati tunjangan sesuai perbup 45/2017. Bupati Roby Idong lewat berbagai media masa menyampaikan bahwa ada dugaan mark-up tunjangan DPRD. Sehingga konflik semakin membesar lewat tindakan Bupati yang meminta BPK (Badan Pemeriksa Keuangan) Provinsi NTT untuk memeriksa dugaan mark up pada Perbup 45/2017 tersebut. Hal ini direspon balik dengan laporan anggota DPRD Siflan Angi yang melaporkan Bupati ke Polres Sikka atas tuduhan pencemaran nama baik karena menyatakan anggota DPRD kemungkinan melakukan mark-up atas dana tunjangan perumahan dan transportasi pada rencana APBD 2019 (Gomez, 2019).

Berbagai Kemudian Seperti diketahui, Bupati Sikka yang terpilih tahun 2018 ini merupakan pemenang kontestasi dari jalur perseorangan. Pada Pemilihan Kepala Daerah tahun 2018 lalu, Kabupaten Sikka untuk pertama kalinya memiliki Bupati dari jalur perseorangan atau independen yang berhasil mengalahkan petahana. Namun, ketika telah menjabat rupanya banyak terjadi konflik kepentingan antara legislatif dan eksekutif di tingkat lokal ini, seperti antara Bupati dan DPRD Kabupaten Sikka dalam perencanaan APBD. Penulis melihat adanya konflik kepentingan antara Bupati dan DPRD dalam penyusunan APBD ini dipengaruhi berbagai faktor. Berdasarkan permasalahan tersebut, penulis merumuskan permasalahan yakni bagaimana terjadinya konflik kepentingan Bupati dan DPRD Kabupaten Sikka dalam pengesahan APBD Tahun Anggaran 2019.

\section{METODE}

Penelitian ini menggunakan metode penelitian sosial secara kualitatif. Moleong (2017) menjelaskan bahwa metode penelitian kualitatif merupakan suatu prosedur 
penelitian yang menghasilkan data berupa naskah wawancara orang-orang yang diamati, catatan lapangan, foto, jejaring, tabel, gambar untuk memperoleh kejelasan makna dari setiap pola perilaku yang ditunjukkan oleh subyek penelitian. Penelitian ini mengumpulkan data primer dengan metode in-depth interview pada pihak yang terlibat konflik, yakni Bupati dan perangkat DPRD Kabupaten Sikka. Sementara itu, data sekunder diperoleh dari media lokal seperti koran dan artikel berita. Secara teoritis, penggunaan metode kualitatif juga memiliki kelebihan tersendiri. Moleong (2017) memaparkan beberapa kelebihan dari metode kualitatif yang pertama, metode ini lebih mudah disesuaikan bila berhadapan dengan kenyataan ganda. Kedua, metode ini menyajikan secara langsung hubungan antara peneliti dan responden. Ketiga, metode ini lebih peka dan dapat menyesuaikan diri dengan banyak penajaman pengaruh bersama dan terhadap pola-pola nilai yang dihadapi. Teknik analisis data menggunakan reduksi, penyajian dan penarikan kesimpulan (Creswell, 2014) yang dilakukan secara sistematis berdasarkan tahapan penelitian.

\section{HASIL DAN PEMBAHASAN}

Tunjangan merupakan salah satu sumber penghasilan bagi anggota legislatif selain gaji pokok. Biaya politik yang besar ketika mencalonkan diri menjadi salah satu penyebab para anggota legislatif bernegosiasi dengan pemangku kepentingan eksekutif terkait angka anggaran yang akan ditetapkan. Konflik sendiri memiliki berbagai pengertian, menurut Rauf (2000) konflik adalah setiap perbedaan pendapat paling tidak antara dua orang atau kelompok, yang dapat berwujud non fisik tanpa kekerasan atau mampu berkembang menjadi kekerasan antar fisik.

Sementara itu, konflik menurut Gurr (1980) dapat terjadi jika: (1) melibatkan lebih dari satu pihak atau lebih dari dua pihak, (2) antar pihak ini kemudian saling berbeda pemahaman dan berseberangan pendapat, (3) selanjutnya terdapat tindakan atau usaha yang memancing dari salah satu pihak untuk mengendalikan pihak lainnya (4) usaha saling mengendalikan antar pihak ini terlihat secara jelas oleh pihak netral atau pengamat sehingga mudah diketahui dan disepakati. Penguasa politik dapat saling berkonflik dengan penguasa lainnya atau pemegang kekuasaan lainnya sehingga menghadirkan konflik kepentingan.

Raperda atau Rancangan Peraturan Daerah terkait APBD 2019 sebenarnya telah diajukan pemerintah Kabupaten Sikka pada bulan November 2018. DPRD kemudian membahas RAPBD berdasarkan UU No.23/2014, tentang Pemerintahan Daerah, dan Permendagri No.28/2018, tentang Pedoman Penyusunan RAPBD Tahun Anggaran 2019. Dilanjutkan dengan DPRD melakukan asistensi RAPBD 2019 dengan provinsi NTT. Namun, TPAD (Tim Penyusun Anggaran Daerah) belum menyertakan dokumen pendukung seperti Peraturan Bupati tentang Standar Harga Satuan Barang dan Biaya Tahun Anggaran 2019. Sekretaris daerah selaku ketua TPAD menyampaikan tidak ada perubahan berarti. Rapat sinkronisasi antara TPAD dan Banggar DPRD. Dalam rapat ini terjadi perbedaan pendapat antara TPAD dan Banggar DPRD. Bupati merubah angka tunjangan anggota DPRD sesuai dengan Perbup No.33/2018, tentang Standar Harga Satuan Barang tahun 2019. Tetapi, Banggar DPRD berpegang pada Perbup No. 45/2017.

Peraturan Bupati No. 33/2018 merupakan peraturan yang dikeluarkan Bupati Sikka periode 2018-2023, Fransiskus Robertus Diogo mengenai Standar Harga Satuan Barang dan Biaya Tahun Anggaran 2019, isinya mengatur biaya tunjangan perumahan anggota DPRD sebesar Rp 6.250.000 setiap bulan untuk anggota dan tunjangan transportasi sebesar Rp 9.000.000 setiap bulan untuk anggota. Sementara itu, Peraturan Bupati Sikka periode 2013-2018 Yoseph Ansar Rera mengenai Standar Harga Satuan Barang dan Biaya Tahun Anggaran 2018, isinya mengatur biaya tunjangan perumahan anggota DPRD sebesar 
Rp 10.000.000 setiap bulan untuk anggota dan tunjangan transportasi sebesar Rp 12.500.000 setiap bulan untuk anggota. Diduga terjadi mark up karena harga yang kemahalan dari ketetapan yang terdapat dalam Peraturan Bupati (Mo'a, 2019).

Dari permasalahan tersebut, terlihat beberapa tindakan yang menunjukkan adanya bentuk konflik. Seperti adanya pelaporan dari anggota legislatif bernama Siflan Angi yang merasa tidak terima atas pemberitaan dan tuduhan Bupati bahwa DPRD telah melakukan mark up tunjangan perumahan dan transportasi selama tahun 2018 dan berencana kembali melakukan hal yang sama pada APBD 2019. Laporan ini diproses di Polres Sikka pada tanggal 15 Agustus 2019.

Sementara itu menurut Rauf (2000) konflik politik ditimbulkan oleh adanya keterbatasan sumber daya dan posisi (resources and position scarcity). Semakin besar tingkat kelangkaan sumber-sumber daya yang dibutuhkan untuk hidup, semakin besar kemungkinan terjadinya konflik politik. Kelangkaan ini tentu terjadi dalam politik terutama jumlah penguasa politik yang jelas lebih sedikit dari jumlah rakyat yang dikuasai. Hal ini menyebabkan jabatan sebagai penguasa politik sangat menarik. Senada dengan salah satu preposisi konflik dalam penelitian Lowi (1995) yang mengatakan bahwa konflik muncul dari kelangkaan posisi dan kelangkaan sumber daya. Kelangkaan posisi adalah suatu keadaan dimana suatu benda tidak dapat menempati dua tempat pada waktu yang sama, suatu benda tidak dapat secara bersamaan melayani dua fungsi yang berbeda, suatu peran tidak dapat secara bersamaan ditempati atau dilakukan oleh dua atau lebih pelaku, dan perilaku yang ditentukan berbeda tidak dapat dilakukan secara bersamaan. Sedangkan resource scarcity adalah kondisi di mana ketersediaan objek (atau keadaan) yang diinginkan dibatasi sehingga pihak-pihak tidak dapat memperoleh semua yang diinginkannya.

Konflik kepentingan yang terjadi antara eksekutif dan legislatif di tingkat lokal ini cenderung disebabkan oleh adanya keterbatasan posisi dan kelangkaan sumber daya. Dalam hal ini yang dimaksudkan dengan keterbatasan posisi ialah jumlah orang yang menjabat sebagai pejabat publik atau anggota DPRD. Sementara itu kelangkaan sumber daya yang dimaksudkan dalam permasalahan ini merujuk pada tunjangan anggaran yang bersumber dari APBD. Dimana seperti kita ketahui, Kabupaten Sikka memiliki PAD (Pendapatan Asli Daerah) yang rendah, sehingga sumber APBD diperoleh dari dana hibah pusat. Hal ini yang kemudian menjadi permasalahan ketika salah satu pihak memutuskan untuk menurunkan angka tunjangan.

Dalam penelitian ini, ditemukan bahwa terdapat kepentingan dari Bupati maupun anggota DPRD saat itu. Kepentingan yang ingin dicapai oleh Bupati salah satunya terkait dengan pemilihan legislatif 2019. Momentum penyusunan APBD ini bertepatan dengan masa kampanye pemilihan anggota legislatif yakni 23 September 2018 - 13 April 2019. Selama masa kampanye pileg ini, tepatnya sejak Bupati Roby Idong dilantik pada 20 September 2018, Bupati Roby Idong terlihat paling gentol membicarakan permasalahan APBD 2019. Bupati Roby Idong menyampaikan dalam beberapa kesempatan wawancara dengan media bahwa anggota DPRD telah melakukan mark up tunjangan. Hal ini membawa opini publik yang negatif terhadap anggota DPRD, terutama bagi mereka yang sedang mencalonkan diri kembali dalam pileg 2019. Menurut wawancara dengan Siflan Angi, salah seorang anggota DPRD kabupaten Sikka 3 periode yakni pada 2004-2019 menyampaikan bahwa terdapat indikasi Bupati menerbitkan Perbup 33/2018 karena adanya ketidaksukaan terhadap anggota DPRD 2014-2019 yang sedang menjabat ini karena berasal dari partai yang tidak mendukungnya ketika maju sehingga akhirnya mencalonkan diri pada Pilkada Sikka tahun 2018 dari jalur perseorangan. Ia juga mengatakan bahwa tindakan Bupati Roby Idong yang mengatakan di berbagai media massa bahwa DPRD 
periode 2014-2019 ini telah melakukan mark up tunjangan transportasi dan perumahan bersama Bupati sebelumnya periode 2013-2018 yakni Mantan Bupati Yosep Ansar Rera (wawancara pada September 2020, di kediaman pribadi beliau).

Selain itu, angka tunjangan anggaran yang diajukan oleh DPRD Sikka periode 20142019 tersebut masih dalam batas normal. Batas normal yang dimaksud adalah selama angka tunjangan tidak melebihi batas angka tunjangan DPRD Provinsi berdasarkan PP No. 18 tahun 2017 tentang Hak Keuangan dan Administrasi Pimpinan dan Anggota DPRD yang disesuaikan dengan keuangan daerah. Hal ini sejalan dengan sejarah prestasi Kabupaten Sikka yang konsisten meraih opini WTP (Wajar Tanpa Pengecualian) dalam audit LKPD (Laporan Keuangan Pemerintah Daerah) nya sejak tahun 2016 hingga 2019. Bahkan, Kabupaten Sikka sempat menjadi satu-satunya kabupaten di Provinsi Nusa Tenggara Timur yang menerima opini WTP ini pada tahun 2016 dan 2017.

Sehingga dalam permasalahan ini, konflik yang terjadi antara Bupati dan DPRD Sikka dipengaruhi oleh kepentingan dari masing-masing pihak. Kepentingan Bupati untuk mengurangi keterpilihan kembali anggota DPRD yang notabene berasal dari partaipartai politik yang menolak mendukung Bupati sewaktu mencalonkan diri pada Pilkada 2018. Berbagai pemberitaan negatif tentang DPRD Sikka yang melakukan mark up dana tunjangan memicu konflik dari anggota DPRD yang tidak terima. Hal ini sangat berdampak buruk bagi anggota DPRD yang sedang dalam masa kampanye untuk Pileg 2019.

\section{KESIMPULAN}

Dari penjelasan diatas, penulis menyimpulkan bahwa kepentingan masing-masing kubu, baik DPRD maupun Bupati terlihat politis dengan memanfaatkan media dan simpati masyarakat. Banyak informasi yang tidak benar dan disiarkan media secara berlebihan sehingga membawa citra negatif bagi anggota DPRD yang saat konflik ini berlangsung sedang dalam masa kampanye Pileg 2019. Terdapat fakta yang saling bertolakbelakang. Seperti Kabupaten Sikka mendapatkan opini WTP dalam audit LKPD nya selama empat tahun berturut-turut sejak 2016, 2017, 2018 dan 2019. Namun, terdapat permasalahan konflik kepentingan antara Bupati dan DPRD mengenai penurunan nominal tunjangan tesebut. Dalam perjalanan konflik tersebut berakumulasi hingga pelaporan ke Kejaksaan Agung. Tidak hanya sampai Kejagung, Bupati Sikka juga dilaporkan karena dianggap melakukan pelecehan nama baik anggota legislatif oleh Siflan Angi.

Jika melihat akumulasi action dalam konflik kepentingan ini, maka dapat terlihat adanya kepentingan-kepentingan dari kedua belah pihak. Kepentingan Bupati Roby Idong dalam permasalahan ini sebenarnya tidak terlihat secara eksplisit. Bupati Roby Idong merupakan bupati yang menag dari jalur perseorangan. Pihak DPRD melihat bahwa kepentingan Bupati Roby untuk menurunkan tunjangan ini sebagai bentuk usaha menjatuhkan citra para anggota DPRD yang sedang memasuki masa kampanye Pileg 2019. Sehigga, setidaknya ketika Pileg 2019 selesai, terpilih angggota-anggota DPRD baru yang diharapkan akan lebih kooperatif bersama Bupati dalam menjalankan roda pemerintahan.

\section{DAFTAR RUJUKAN}

Ananta, D. D. (2016). Politik Oligarki dan Perampasan Tanah di Indonesia: Kasus Perampasan Tanah di Kabupaten Karawang Tahun 2014. Jurnal Politik, 2(1), 101133. https://doi.org/10.7454/jp.v2i1.83

Asari, N. M. A., \& Suardana, K. A. (2018). Pengaruh Pendapatan Asli Daerah, Dana Perimbangan, dan Lain-Lain Pendapatan Daerah yang Sah pada Belanja Daerah. EJurnal Akuntansi, 25(2), 877-904. https://doi.org/10.24843/eja.2018.v25.i02.p03

Barbakem, D. I., Tinangon, J. J., \& Sabijono, H. (2018). Analisis Perencanaan dan 
Penganggaran untuk Anggaran Pendapatan dan Belanja Daerah Pada Badan Keuangan Kabupaten Kepulauan Sangihe Tahun Anggaran 2015. Jurnal Riset Akuntansi Going Concern, 13(1), 1-13. https://doi.org/10.32400/gc.13.01.18819.2018

Creswell, J. W. (2014). Research design: Qualitative, quantitative, and mixed methods approaches (4th ed.). Thousand Oaks, CA: Sage.

Eddyono, L. W. (2010). Penyelesaian Sengketa Kewenangan Lembaga Negara oleh Mahkamah Konstitusi. Jurnal Konstitusi, $7(3), \quad 1-48$. https://doi.org/10.31078/jk\%25x

Ferdian, Y. (2013). Pengaruh Pendapatan Asli Daerah, Dana Perimbangan, dan Lain-lain Pendapatan Yang Sah Terhadap Belanja Daerah. Jurnal Akuntansi, 1(2), 1-27. http://ejournal.unp.ac.id/students/index.php/akt/article/view/644

Gomez, V. Da. (2019). Pidanakan Bupati Sikka, Siflan Angi Diperiksa 3,5 Jam. SuaraSikka.Com. https://suarasikka.com/2019/08/22/pidanakan-bupati-sikkasiflan-angi-diperiksa-35-jam/

Gurr, T. R. (1980). Handbook of Political Conflict: Theory and Research (The Free Press series on political behavior). Free Press.

Halim, A., \& Abdullah, S. (2006). Hubungan dan Masalah Keagenan di Pemerintahan Daerah: Sebuah Peluang Penelitian Anggaran dan Akuntansi. Jurnal Akuntansi Pemerintahan, 2(1), 53-64.

Hutapea, B. (2015). Dinamika Hukum Pemilihan Kepala Daerah di Indonesia. Jurnal Rechts $\begin{array}{llll}\text { Vinding: } \quad M e d i a \quad P e m b i n a a n & \text { Hukum }\end{array}$ https://doi.org/10.33331/rechtsvinding.v4i1.136

Ibrahim. (2014). Perencanaan Penganggaran Daerah. Jurnal Akuntansi Dan Pajak, 15(1), 98-111. https://doi.org/10.29040/jap.v15i01.215

Lontaan, I. C., \& Pangerapan, S. (2016). Analisis Belanja Daerah pada Pemerintah Kabupaten Minahasa Tahun Anggaran 2012-2014. Jurnal EMBA: Jurnal Riset Ekonomi, Manajemen, Bisnis Dan Akuntansi, 4(1), 898-906. https://doi.org/10.35794/emba.v4i1.11820

Lowi, M. R. (1995). WATER AND POWER. The Politics of a Scarce Resource in the Jordan River Basin (R. B. Betts (ed.)). Cambridge University Press.

Masyrofah. (2013). Arah Perubahan Sistem Pemilu dalam Undang-Undang Politik Pasca Reformasi. Jurnal Cita Hukum, 1(2), 165-175. https://doi.org/10.15408/jch.v1i2.2988

Mo'a, E. (2019). Bupati Sikka Tak Bayangkan Tunjangan Transportasi dan Perumahan DPRD Dilaporkan ke Polisi. Pos-Kupang.Com. https://kupang.tribunnews.com/2019/09/20/bupati-sikka-tak-bayangkantunjangan-transportasi-dan-perumahan-dprd-dilaporkan-ke-polisi

Moleong, L. J. (2017). Metodologi Penelitian Kualitatif (Revisi). PT. Remaja Rosdakarya.

Oktora, F. E., \& Pontoh, W. (2013). Analisis Hubungan Pendapatan Asli Daerah, Dana Alokasi Umum, Dan Dana Alokasi Khusus Atas Belanja Modal Pada Pemerintah Daerah Kabupaten Tolitoli Provinsi Sulawesi Tengah. Accountability, 2(1), 1-10. https://doi.org/10.32400/ja.2337.2.1.2013.1-10

Pramono, J. (2014). Analisis Rasio Keuangan Untuk Menilai Kinerja Keuangan Pemerintah Daerah. Jurnal Ilmiah Among Makarti, 7(1), 83-112. https://jurnal.stieama.ac.id/index.php/ama/article/view/97

Puspitasari, R. (2013). Studi Penganggaran Berbasis Kinerja pada Pemerintah Provinsi Jawa Timur, Jawa Barat dan DKI Jakarta. Jurnal Jejaring Administrasi Publik, 5(2), 356-369. http://journal.unair.ac.id/index.php/JBE/ADMP@studi-penganggaran- 
berbasis-kinerja-pada-pemerintah-provinsi-jawa-timur,-jawa-barat-dan-dkijakarta-article-9239

Rahmawati, M., \& Fajar, C. M. (2017). Pengaruh Pendaptan Asli Daerah Dan Dana Perimbangan Terhadap Belanja Daerah Kota Bandung. Jurnal Kajian Akuntansi, 1(1), 63-76. https://doi.org/10.33603/jka.v1i1.445

Ramdhani, H. (2019). Realitas Elit Politik Lokal dan Persepsi Masyarakat dalam Proses Pemekaran Daerah. JPPUMA Jurnal Ilmu Pemerintahan Dan Sosial Politik Universitas Medan Area, 7(2), 219-226. https://doi.org/10.31289/jppuma.v7i2.3014

Ramdhani, H., \& Subekti, V. S. (2020). Dynamic Local Political Elite in Process for Proposing Regional Expansion. JIP (Jurnal Ilmu Pemerintahan) : Kajian Ilmu Pemerintahan Dan Politik Daerah, 5(1), 1-11. https://doi.org/10.24905/jip.5.1.2020.1-11

Rauf, M. (2000). Konsensus dan konflik politik: sebuah penjajagan teoritis. Direktorat Jenderal Pendidikan Tinggi.

Sofianto, A. (2019). Integrasi Target dan Indikator Sustainable Development Goals (SDGs) ke Dalam Perencanaan Pembangunan Daerah di Jawa Tengah. Jurnal Litbang Provinsi Jawa Tengah, 17(1), 25-41. http://ejournal.bappeda.jatengprov.go.id/index.php/jurnaljateng/article/view/784

Sudirman. (2012). Dinamika politik lokal dalam social capital (modal sosial). Academica, $4(1)$ 741-840. http://jurnal.untad.ac.id/jurnal/index.php/academica/article/view/2267

Supena, C. C. (2018). Peningkatan Fungsi Legislatif Dewan Perwakilan Daerah Melalui Usul Amandemen Undang-Undang Dasar Negara Republik Indonesia Tahun 1945. Dinamika: Jurnal Ilmiah Ilmu Administrasi Negara, 5(4), 39-46. https://doi.org/10.25157/dinamika.v5i4.1745

Tim Kajian PKP2A III LAN Samarinda. (2010). Efektifitas Perencanaan Pembangunan Daerah di Kalimantan. Jurnal Borneo Administrator: Media Pengembangan Paradigma Dan Inovasi Sistem Administrasi Negara, 6(1), 1-21. https://doi.org/10.24258/jba.v6i1.55

Widiasih, N. N., \& Gayatri. (2017). Pengaruh Pendapatan Asli Daerah, Dana Alokasi Umum, Dana Bagi Hasil Pada Belanja Modal Kabupaten/Kota di Provinsi Bali. E-Journal Akuntansi Universitas Udayana, 18(3), 2143-2171. https://ojs.unud.ac.id/index.php/Akuntansi/article/view/25832

Widodo, W. (2014). Peran Dan Fungsi DPD RI Dalam Rangka Menuju Sistem Bikameral Yang Efektif Melalui Amandemen. Jurnal Pembaharuan Hukum, 1(2), 121-131. https://doi.org/10.26532/jph.v1i2.1462

Williantara, G. F., \& Budiasih, I. G. A. N. (2016). Pengaruh Pendapatan Asli Daerah, Dana Alokasi Umum, Dana Alokasi Khusus, Dan Dana Bagi Hasil Pada Indeks Pembangunan Manusia. E-Jurnal Akuntansi, 16(3), 2044-2070. https://ojs.unud.ac.id/index.php/Akuntansi/article/view/19203

Yasin, M. (2020). Analisis Pendapatan Asli Daerah Dan Belanja Pembangunan Terhadap Pertumbuhan Ekonomi Di Kabupaten/Kota Jawa Timur. JCOSTING: Ournal of Economic, Business and Accounting, 53(9), 1689-1699. https://doi.org/10.31539/costing.v3i2.1161 